\title{
ALCOHOL AND ITS EFFECTS ON SPRINT AND MIDDLE DISTANCE RUNNING
}

\author{
L. McNAUGHTON, PhD* and D. PREECE, BEd** \\ *Tasmanian State Institute of Technology, Launceston, Tasmania \\ **Physical Education Teacher, Launceston, Tasmania
}

\begin{abstract}
Alcohol has been used as an aid to performance for a considerable period of time in many athletic endeavours. Five sprinters and five middle distance athletes were tested to determine whether differing levels of alcohol $\left(0.01 \mathrm{mg}^{\mathrm{ml}} \mathbf{l}^{-1}, 0.05 \mathrm{mg}^{-1} \mathrm{ml}^{-1}\right.$ and $0.10 \mathrm{mg} \cdot \mathrm{ml}^{-1}$ ) had differing effects upon performance times in the $100 \mathrm{~m}, 200 \mathrm{~m}, 400 \mathrm{~m}, 800 \mathrm{~m}$ and $1500 \mathrm{~m}$ events. Blood alcohol concentration (BAC) was estimated from breath alcohol concentration (BrAC) using a hand held Drager Alcotest 7310 and a Borkenstein Breathalyser. Alcohol affected all but the $100 \mathrm{~m}$ event to varying degrees. In the $200 \mathrm{~m}$ the performance decreased when the level of intoxication increased. This was not the case in the $400 \mathrm{~m}$ which showed a difference between the two lower levels of alcohol consumption $\left(0.01 \mathrm{mg} \cdot \mathrm{ml}^{-1}\right.$ to $\left.0.05 \mathrm{mg} \cdot \mathrm{ml}^{-1}\right)$ but not between the $0.05 \mathrm{mg} \cdot \mathrm{ml}^{-1}$ and $0.10 \mathrm{mg} \cdot \mathrm{ml}^{-1}$. In the middle distance events the $800 \mathrm{~m}$ was most adversely affected. We concluded that alcohol is not an ergogenic aid in so much that it does not improve performance. In the $100 \mathrm{~m}$ events, performance remained stable. More research in this area is warranted.
\end{abstract}

Key words: Alcohol, Anaerobic, Aerobic, Ergogenic aid.

\section{INTRODUCTION}

It has been claimed that alcohol can be used as an ergogenic aid to improve sports performance (Lamb, 1978; Golding, 1972). Stockley (1981) however, claims that alcohol is a depressant and the American College of Sports Medicine (1982) agrees with this view, and has concluded that alcohol has no beneficial effect on work capacity. This is supported by the work of Bond et al. (1984) and Blomqvist et al. (1970) who found that small or moderate doses of alcohol had no beneficial effect on work performance.

Observations by Delgado (1975), Nankano and Moore (1971) and Webb et al. (1967), all support the notion that alcohol consumption before exercise decreases myocardial contractility. This has obvious negative ramifications for endurance exercise. Associated with this is the finding by both Januszewski and Klimek (1974) and Blomqvist et al. (1970) that alcohol ingestion impairs ventilation.

Some possible positive side effects of alcohol ingestion are that it may decrease lactic acid output following anaerobic exercise (Chui, 1978), it provides energy, and reduces anxiety (Smith, 1976).

This research attempted to determine the effects of various levels of alcohol ingestion on various running performances using time as a practical measure of performance, in order to determine whether alcohol could be used as an ergogenic aid.

\section{METHODS}

\section{Subjects}

Five sprinters aged between 19-30 years $(X=22.2 \pm 4.49$ years) were randomly chosen from a list of 1983-84

\author{
Address for correspondence: \\ Dr. Lars McNaughton \\ PO Box 1214 \\ Tasmanian State Institute of Technology \\ Launceston \\ Tasmania 7250 \\ AUSTRALIA
}

Tasmanian Amateur athletes (Northern) as were five middle distance runners. These latter subjects ranged in age from $19-54$ years $(X=30.2 \pm 14.5$ years). The sprinters were both taller $(178.3 \pm 4.41 \mathrm{~cm}$ as compared to $175.0 \pm 8.50 \mathrm{~cm})$ and heavier $(71.6 \pm 4.22 \mathrm{~kg}$ as compared to $65.2 \pm 5.50 \mathrm{~kg})$ than their endurance counterparts. The differences between height and weight were statistically significant $(p<0.05$ and $p<0.005$ respectively). All athletes were still competing in open competition.

\section{Procedures}

Each athlete in the sprinting and middle distance group underwent time trials at four levels of alcoholic tolerance. These correspond to $0.00 \mathrm{mg} \cdot \mathrm{ml}^{-1}, 0.01 \mathrm{mg} \cdot \mathrm{ml}^{-1}$, $0.05 \mathrm{mg} \cdot \mathrm{ml}^{-1}$ and $0.10 \mathrm{mg} \cdot \mathrm{ml}^{-1}$. The athletes in the sprinting group ran the $100 \mathrm{~m}, 200 \mathrm{~m}$ and $400 \mathrm{~m}$ while the middle distance athletes ran the $800 \mathrm{~m}$ and $1500 \mathrm{~m}$.

On the day of testing a group of subjects reported to the track for testing, after fasting for eight hours. The experiment was carried out in a single-blind fashion, with the control run $\left(0.00 \mathrm{mg} \cdot \mathrm{ml}^{-1}\right)$ always being the first of the trials. Prior to the experimental trials $10.01 \mathrm{mg} \cdot \mathrm{ml}^{-1}$ $0.05 \mathrm{mg} \cdot \mathrm{ml}^{-1}$ and $0.10 \mathrm{mg} \cdot \mathrm{ml}^{-1}$ ) the subjects were assigned an amount of vodka contained in orange juice which had been calculated to increase their blood alcohol concentration (BAC) to the desired amount. In the control run $\left(0.00 \mathrm{mg} \cdot \mathrm{ml}^{-1}\right)$ the subjects were given pure orange juice. A noseclip was used to help disguise the experimental liquid. Vodka was chosen as it has the least congeners of any alcohol (Gillies and Mercer, 1978). Orange juice was used as the diluent to provide rapid entrance into the bloodstream (Himwich, 1969). A hand held Drager Alcotest 7310 was used initially to estimate blood alcohol concentration (EBAC) from breath alcohol concentration (BrAC) which was the final measure used prior to the subjects' run. This was the measure used for the results.

The subjects competed against each other in a standard racing format and time was used as the practical measure of performance. Three trial runs were made during the same day at each distance, with the best being used as the subject's final score. The time between trials was used to 
maintain the subjects at their particular EBAC which was monitored constantly by BrAC using the Drager Alcotest 7310 and just prior to the next trial, the Borkenstein Breathalyser. Sprint subjects reported three times in a three week period for their experimental trials $(100 \mathrm{~m}, 200 \mathrm{~m}$ and $400 \mathrm{~m}$ ) while the middle distance subjects reported twice in a two week period for their experimental trials $(800 \mathrm{~m}$ and $1500 \mathrm{~m})$.

\section{Experimental Design and Analysis}

The experiment was conducted in two parts, each being a completely randomised, repeated measures design (Keppel, 1982). In other words, for example, the five subjects in the sprinting group underwent trials of each distance $(100 \mathrm{~m}, 200 \mathrm{~m}$ and $400 \mathrm{~m})$ under each level of BrAC (0.00 mg. $\mathrm{ml}^{-1}$, -control run; $0.01 \mathrm{mg} \cdot \mathrm{ml}^{-1}, 0.05 \mathrm{mg}^{-1} \mathrm{ml}^{-1}$ and $0.10 \mathrm{mg} \cdot \mathrm{ml}^{-1}$ ). When appropriate the Newman Keuls procedure was used to locate the source of the significant difference. Alcohol is referred to as level A while distance is referred to as level $B$ throughout the results section.

\section{RESULTS AND DISCUSSION}

The results and discussion section will be in two sections. The first of these will deal with information relevant to the sprinting group while the latter section will deal with the middle distance athletes.

\section{Sprinting Group}

The sprinting group showed a significant $A$ (Alcohol) $x$ $B$ (Distance) interaction ( $p<0.01$ ), that is different levels of alcohol had a different effect at the different distances run by the athletes. Furthermore there was significant main effect $A(p<0.001)$ and, necessarily, a main effect $B$ (time, $p<0.05$ ) because running longer distances takes a longer period of time. A post hoc analysis of the $A \times B$ interaction was carried out on the simple main effects of factor $A$ at different running distances within the running group. Surprisingly, there was no statistically significant effect of alcohol at the $100 \mathrm{~m}$ distance. That is, no level of alcohol detrimentally effected the running of the $100 \mathrm{~m}$ sprint.

At the $200 \mathrm{~m}$ and $\mathbf{4 0 0} \mathrm{m}$ distances there was a statistically significant effect of alcohol ( $p<0.025$ and $p<0.01$ respectively) on sprinting performance. In order to determine whther different levels of alcohol significantly affected running time in the $200 \mathrm{~m}$ and $\mathbf{4 0 0} \mathrm{m}$, post hoc comparisons involving individual means was undertaken. In the $\mathbf{2 0 0} \mathrm{m}$ as the BrAC increased so did the performance decrement. This was not the case in the $400 \mathrm{~m}$. In this instance alcohol had a significant effect at lower levels of BrAC (0.01 mg. ml-1 and $\left.0.05 \mathrm{mg} \cdot \mathrm{ml}^{-1}\right)$ where performance decreased, but at higher levels of BrAC (between $0.05 \mathrm{mg} \cdot \mathrm{ml}^{-1}$ and $0.10 \mathrm{mg} \cdot \mathrm{ml}^{-1}$ ) no such decrement was seen. The effects of varying levels of BrAC may be seen in Fig. 1 and it is interesting to note here both the non-effect of alcohol in the $100 \mathrm{~m}$ performance and the performance asymptote in the $400 \mathrm{~m}$ after the $0.05 \mathrm{mg} \cdot \mathrm{ml}^{-1}$ level.

We are unable to theorise as to the possible reasons why alcohol has no effect on $100 \mathrm{~m}$ running performance. Hebbelinck (1963) noted a ten per cent deterioration in performance over the $80 \mathrm{~m}$ dash, $\mathbf{3 0}$ minutes after a small quantity of alcohol was ingested. In our research, after an initial decrease in performance time at the $0.01 \mathrm{mg} \cdot \mathrm{ml}^{-1}$ $\mathrm{BrAC}$, there was an increase in time but only approximately five per cent, which was not statistically significant. Clearly,
Performance

Time (seconds)
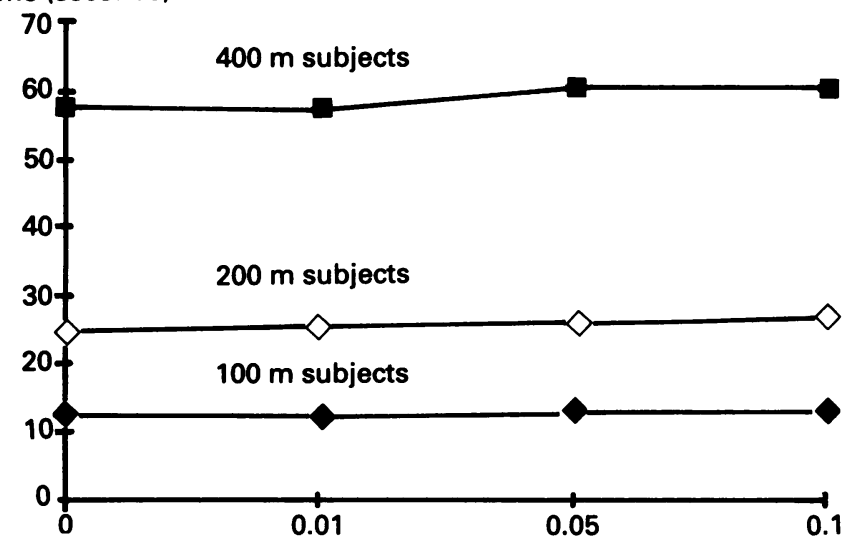

Breath Alcohol Concentration (mg. $\mathbf{m l}^{-1}$ )

Fig. 1: The effects of varying amounts of alcohol on $100 \mathrm{~m}, 200 \mathrm{~m}$ and $400 \mathrm{~m}$ performance (standard deviation was $<0.68$ second in all cases).

more work needs to be undertaken as to the effects of alcohol on anaerobic performance. As to the decrements in the $200 \mathrm{~m}$ and $400 \mathrm{~m}$ performance, Williams (1979) found that complex motor skills such as running, can be affected by very low blood alcohol concentrations. Further Leighninger et al. (1961) found that muscular efficiency decreased with the ingestion of alcohol and clearly this could affect performance. Unfortunately we cannot suggest possible reasons for the asymptote in performance between the $0.05 \mathrm{mg} \cdot \mathrm{ml}^{-1}$ and $0.10 \mathrm{mg} \cdot \mathrm{ml}^{-1} \mathrm{BrAC}$ during the running of the $400 \mathrm{~m}$.

\section{Middle Distance Group}

The $800 \mathrm{~m}$ was the shortest of the two distances over which the middle distance athletes were tested and it was also the most adversely affected. The effects of the different estimated levels of blood alcohol were statistically significant for both the $800 \mathrm{~m}$ and the $1500 \mathrm{~m}$ but more so for the $800 \mathrm{~m}$ ( $p<0.001$ and $p<0.05$ respectively). In the $800 \mathrm{~m}$ as the BrAC increased so performance decreased, this can be seen in Fig. 2. The difference between the $0.01 \mathrm{mg} \cdot \mathrm{ml}^{-1}$ and the $0.05 \mathrm{mg} \cdot \mathrm{ml}^{-1}$ etimated blood alcohol concentration was statistically significant $(p<0.05)$ while the difference between the $0.05 \mathrm{mg} \cdot \mathrm{ml}^{-1}$ and the $0.10 \mathrm{mg} \cdot \mathrm{ml}^{-1} \mathrm{BrAC}$ was significant at the 0.001 level.

The $800 \mathrm{~m}$ is of a more aerobic nature than the $100 \mathrm{~m}$, $200 \mathrm{~m}$ and $400 \mathrm{~m}$ and possibly is affected to a greater extent by a decrease in stroke volume, brought about by a decreased myocardial contractility (Markiewicz and Cholewa, 1982; Januszewski and Klimek, 1974). Another of the effects of alcohol on the body, observed by Blachley et al. (1980), Horowitz and Atkins (1972) and Cook and Brown (1932), is that ethanol induces cutaneous vasodilation. This may have an adverse effect on the $800 \mathrm{~m}$ runner, one that might increase with an increase in BAC which is in relation to heat loss. The $800 \mathrm{~m}$ runner has a greater potential to lose heat than does the sprinter because of the time spent on the track. Ethanol increases cutaneous vasodilation and the blood is therefore exposed to cool circulating air as the athlete runs. This in turn could increase the viscosity of the blood which would mean that the muscles would not function as well and performance would decrease. This is in agreement with the work of Leighninger et al. (1961), who 


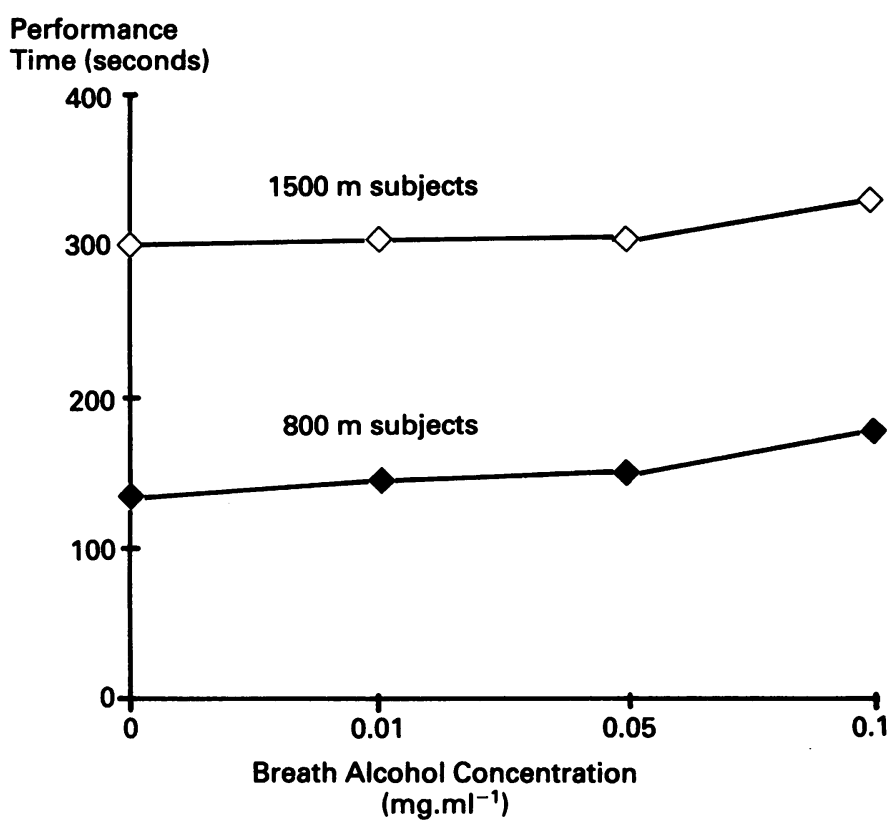

Fig. 2: The effects of varying amounts of alcohol on $100 \mathrm{~m}, 200 \mathrm{~m}$ and $400 \mathrm{~m}$ performance (standard deviation was < 3.2 seconds in the $800 \mathrm{~m}$ and $<8.7$ seconds in the $1500 \mathrm{~m}$ ).

found a decrease in blood supply to the working muscle after alcohol ingestion. The comment by some middle distance runners that they appeared to be sweating more than usual is consistent with this explanation.

Another factor here is that ethanol ingestion has been claimed by some (Strauss, 1982) to increase levels of lactic acid which might induce a state of fatigue earlier than when no alcohol is ingested. This is, however, in disagreement with the findings of Chui (1978) who found that 90 minutes after alcohol was ingested there were decreased levels of lactic acid in muscle tisue after ischaemic arm exercise.

A final factor which may have influenced the running of the $800 \mathrm{~m}$ is the inhibitory effects of alcohol on gluconeogenesis from lactate which takes place in the liver. According to both Fox (1984) and Stryer (1981) some of the lactic acid produced during exercise may be transformed through gluconeogenesis in the liver to blood glucose. This process is inhibited by alcohol and presumably the levels of lactate which would have been produced in the $800 \mathrm{~m}$ could have been used as fuel for exercise. The time period of the $800 \mathrm{~m}$ may not be long enough for this to be the case but certainly in the post-exercise state the alcohol would inhibit the replenishment of muscle glycogen through the glucose produced in the liver (Fox, 1984).

The $1500 \mathrm{~m}$, the longer of the two middle distance events was affected across most of the levels of EBAC but to a lesser extent than was the $800 \mathrm{~m}$ (see Fig. 2). As performance was adversely affected, it could be said that the same factors affecting the $800 \mathrm{~m}$ performance may have been in operation during the $1500 \mathrm{~m}$ performance. These include, lack of co-ordination (Williams, 1979), decreased myocardial contractility (Markiewicz and Cholewa, 1982; Januszewski and Klimek, 1974 and Gould, 1970), decreased lung ventilation and carbon dioxide discharge (Blomqvist et al., 1970) and enhanced cutaneous vasodilation (Blachley et al., 1980; Horowitz and Atkins, 1974). One might therefore ask why alcohol was less affected than the $800 \mathrm{~m}$. The reason may lie in the greater aerobic nature of this particular form of exercise. If alcohol does in fact increase lactic acid concentration then possibly there is less feeling of fatigue during this race than in the $800 \mathrm{~m}$ and the runners can perform closer to their potential. It may also be possible that the energy available from the alcohol could be used by muscle tissue, although this seems unlikely to influence performance over such a short time period.

\section{CONCLUSION}

Alcohol is not an ergogenic aid in so much that it does not improve performance. Clearly, in all but the $100 \mathrm{~m}$ sprint, differing levels of alcohol had differing, but consistently detrimental, effects on timed performance. In the $100 \mathrm{~m}$ there was no such detrimental effect on timed performance but neither was there any positive effect on running performance. We would therefore not recommend the use of alcohol in sprinting performance. Further research is required into the effects of alcohol during anaerobic exercise to determine its effects.

\section{References}

American College of Sports Medicine, 1982 "The use of alcohol in sports". Med .\& Sci.Sports \& Exer. 14: 481-482.

Blachley, J., Fergusen, E. R., Long, J. T. and Knochel, J. P., 1980 "Normal resting and exercising muscle blood flow during acute ethanol infusion". Clin. Toxicol. 17 (3): 413-419.

Blomqvist, C., Saltin, B. and Mitchell, J. H., 1970 "Acute effects of ethanol ingestion on the response to submaximal exercise in man". Circulation 42: 463-470.

Bond, V., Franks, B. D. and Howley, E. T., 1984 "Alcohol, cardiorespiratory function and work performance". Brit.J.Sports Med. 18 (3): 203-206.

Chui, L., 1978 "Effect of ethanol on lactic acid production by exercised normal muscle". Muscle and Nerve 57-61.

Cook, D. and Brown, C., 1932 "The vasodilation effect of ethyl alcohol in peripheral arteries". Proc. Staff Meeting Mayo Clinic 7: 449.

Delgado, C., 1975 "Acute effects of the low doses of alcohol on left ventricular function by echocardiography". Circulation 51: 535-540.

Fox, S. I., 1984. Human Physiology. Dubuque, lowa, Wm. C. Brown Publishers.

Gillies, O. and Mercer, D., 1978. The Sunday Times Book of Body Maintenance. London, Michael Joseph Ltd.

Golding, L. A., 1972. Drugs and Hormones, In: Morgan, W. P. (Ed.), Ergogenic Aids and Muscular Performance, New York, Academic Press, pp. 368.

Gould, L., 1970 "The cardiac effects of alcohol". Am. Heart J. 79: 422-425.

Hebbelinck, M., 1963 "The effects of a small dose of ethyl alcohol on certain basic components of human physical performance II. The effect on neuromuscular performance". Arch.Int. Pharmacondyn 143: 247-257.

Himwich, H. E., 1969 "The physiology of alcohol in man". Am. Heart J. 78: 133-135.

Horowitz, L. and Atkins, J., 1974 "Acute effects of ethanol on left ventricular performance". Circulation 49: 124-128.

Januszewski, J. and Klimek, A., 1974 "The effect of small doses of alcohol on haemodynamics and metabolism during exercise". Acta Physiol.Scand. 25: 533-540.

Keppel, G., 1982. Design and Analysis: A Researcher's Handbook. New Jersey, Englewood Cliffs.

Lamb, D. R., 1978. Physiology of Exercise. New York, Macmillan Pub. Co.

Leighninger, D. S., Rueger, R. and Beck, C. S., 1961 "Effect of pentaerythritol tetranitrate, amyl nitrite and alcohol on arterial blood supply to ischemic myocardium". Am.J.Cardiol. 7: 533-539.

Markiewicz, K. and Cholewa, M., 1982 "The effect of alcohol on the circulatory system adaptation to physical effort". J.Stud.Alcohol 43 (7): 812-823. 
Nankano, J. and Moore, S., 1971 "Effects of alcohol on equiosmolar sucrose on myocardial contractility". Circulation 44 (Suppl. 2) abstract 75.

Smith, N. J., 1976. Food for Sport. California, Bull Pub. Co.

Strauss, B. J., 1982. Alcohol, In: Wahlqvist, M. L. (Ed.). Food and Nutrition in Australia, Ryde. N.S.W., Methuen Australia Ltd.
Stryer, L., 1981. Biochemistry. San Francisco, W. H. Freeman \& Co. Webb, W. R., Gupta, D. N., Cook, W. A., Sugg, W. L., Bashoor, F. A and Unal, M. O., 1967 "Effects of alcohol on myocardial contractility". Diseases of the Chest 52: 602-607.

Williams, M. H., 1979 "Alcohol and athletes: a round table conference". Physician \& Sportsmed. 77: 40-51.

\section{BOOK REVEW}

\section{Title: LUGAMENT INJURIES AND THEIR TREATMENT}

Editor: $\quad$ D. H. R. Jenkins

Publishers: $\quad$ Chapman and Hall, London

Price: $₫ 35.00364$ pages incl. index Hard back 19 contributors to 16 chapters ISBN 0-412-25470-0

The book starts off with a good review of the anatomy and biomechanics of ligament systems and their healing process with special reference to the knee and elbow and ankle which are the principal sites of ligament injury in man with the exception of the metacarpo-phalangeal joint of the thumb.

Clinical emphasis is mainly on the knee with a survey of the presenting features and diagnosis of the various instabilities and their management.

The editor's known interest and pioneer work with carbon fibre is reflected in the disproportionate emphasis on this material for ligament repair. Almost a third of the book is devoted to carbon fibre. Its brittleness and tendency to fragment with time and for its particles to migrate may modify its further use.

Little mention has been given to arthroscopic techniques for ligament repair which are presently in vogue.

This book is mainly of interest to orthopaedists who are concerned with the management of joints liable to ligament sprains or tears. It is, I think, somewhat too technical for the average lay reader.

B. Helal

\section{BOOK REVEW}

Title:

INJURIES TO THE THROWNG ARM

Editors: $\quad$ B. Zarins, J. R. Andrews and W. G. Carson

Publisher: $\quad$ W. B. Saunders Co. 1985

Price: $£ 39.50 \quad 372$ pages Index Half-tone and graphs Soft back ISBN 0-7216-1416-7

Much of the appeal of this book would not be possible without the aid of Channel 4 TV. It is an American publication dealing mainly with the upper limb problems of baseball players, introducing such problems as Little Leaguer's elbow and evaluating the fast ball, curve ball and the slider. One section is devoted to tennis and swimming but there is no mention of other racquet sports or field events.

It is a book which could interest the rising Orthopaedic surgeon or physician, with detailed accounts of surgical and radiographic techniques. Whilst the authors admit that arthroscopy of the shoulder and elbow is not firmly established, their enthusiasm for the technique is unmistakable in their detailed accounts.

The chapters on body mechanics and functional anatomy, together with the description of common injuries and their evaluation are excellent. Inevitably, with a compilation such as this, illustration is variable but where they are included they are of a high standard and helpful.

Treatment may reflect different national attitudes. Remedial and strengthening exercises are dealt with in considerable detail. The programmes appear more appropriate to the remedial gymnast than the physiotherapist and there is no mention of the more technical modalities.

As well as surgery, the various authors do seem keen on steroid injections and, unfortunately, still recommend Phenylbutazone. The more acceptable NSAID's are not recognised in this book.

Its price of $\mathbf{f 3 9 . 5 0}$ presumably reflects the editor's opinion that this compilation of papers from two sports medicine conferences represents the "state of the art" of treatment of throwing injuries. They overvalue its importance. 